\title{
PROFILE OF PATIENTS USING NASOENTERIC PROBE AT THE ADULT EMERGENCY SERVICE IN A PUBLIC HOSPITAL
}

\author{
Mariana Arioza Fernandes Almeida¹, Mahmud Ahmad Ismail Mahmud², \\ Simone Augusta Finard ${ }^{2}$
}

\begin{abstract}
Introduction: Part of the prognosis of hospitalized patient depends on nutritional status and the safety and efficacy of the feeding administration route. Therefore, the aim of this study was to identify data on the indication of nasoenteric tube (NET) prescription to analyze the profile of these patients.
\end{abstract}

Methods: A retrospective cross-sectional study was carried out with data collection in medical records of patients over 18 years of age, of both sexes, treated at the Emergency Adult Service (EAS), using NET.

Results: there was a predominance of females (51.9\%); neurological disease was the most prevalent underlying disease, and $57.8 \%$ had more than one diagnosed disease. Malnutrition, bronchopneumonia, and dysphagia were present in $23.6 \%$, $27 \%$ and $40 \%$ of the cases, respectively. There was a request for speech-language evaluation in only $8.7 \%$ of the patients. And $80.7 \%$ did not use NET prior to emergency care. Regarding the indications for the use of NET by group of underlying disease, low food intake was the most prevalent clinical reason described in the medical records, followed by dysphagia, with a higher prevalence of patients taking NET for nutritional reasons. There was no justification for prescription in $15.2 \%$ of the sample. There was an association between the variables bronchopneumonia and dysphagia $(p=0.01)$.

Conclusion: It was verified that in the studied population there are risk factors for dysphagia. The analysis of the population profile in the present study contributed to increased knowledge and information about this population regarding the criteria for indication of the use of the alternative route.

Keywords: Deglutition disorders; enteral nutrition; emergency medical services

Part of the prognosis of hospitalized patients depends on the nutritional status, which in turn, depends on safety and efficacy of food route. Therefore, proper and safe nutrition is essential and part of the treatment. The patient may be maintained nourished via three nutrition routes, oral (VO), enteral and parenteral. The choice of route depends on the clinical conditions of the patients, the integrity of the gastrointestinal tract (GIT) and their general condition. Nasoenteric catheterization is the most commonly used technique for enteral nutritional therapy (ENT). In addition to the low cost, its introduction can be performed at the bedside and several times if the catheter is removed voluntarily or accidentally. The Nasoenteric Probe (NEP) serves as the access route to the patient's stomach duodenum or jejunum, and is used in ENT. The procedure consists of the insertion of a sterile catheter, nasally, until the stomach, duodenum or jejunum. It is indicated when oral intake is insufficient to reach two-thirds to three-quarters of daily nutritional requirements or, in case of malnutrition, for patients in which the digestive tract is fully or partially functional. It should be indicated when the need to use it is from at least five to seven days for up to six weeks ${ }^{1,2}$.

http://seer.ufrgs.br/hcpa

(cc)BY

ISSN 2357-9730
Clin Biomed Res. 2018;38(3):265-272

1 Programa de Residência Integrada Multiprofissional em Saúde, Hospital de Clínicas de Porto Alegre (HCPA). Porto Alegre, RS, Brasil.

2 Serviço de Fisiatria, Hospital de Clínicas de Porto Alegre (HCPA). Porto Alegre, (RS), Brasil.

Corresponding author:

Mariana Arioza Fernandes Almeida marianaarioza@hotmail.com Hospital de Clínicas de Porto Alegre (HCPA)

Ramiro Barcelos, 2350.

90035-903, Porto Alegre, RS, Brasil. 
Dysphagia is within the fields of action of the phonoaudiologist, and it is with the feeding of these patients that the speech pathologist acts, focusing on swallowing and chewing, since changes in these functions can lead to conditions of malnutrition and/or aspiration ${ }^{3,4}$. Dysphagia is a symptom often found in outpatient or inpatient settings ${ }^{5,6}$, which may lead to serious problems, such as tracheal aspiration, pneumonia, malnutrition, dehydration, and death ${ }^{7,8}$. It is the responsibility of the Speech-Language Pathologist, attributed by CFFa n. 383 from March, $20,2010^{9}$, the prevention, assessment, diagnosis, functional habilitation/rehabilitation of swallowing and management of swallowing disorders.

The oral route $(\mathrm{OR})$ is the preferred way of nutrition. However, due to the impossibility of using this route, the speech therapist, together with the nutrition and medical team, is responsible for the definition of the safest nutritional route, as well as the consistency and volume of the diet to be administered also due to the potential risks of bronchoaspiration. Regarding the type of alternative feeding route, the NEP alone may interfere with the physiology of swallowing.

A study carried out in the Emergency Room of a university hospital showed that more than $50 \%$ of the population treated is dysphagic or present risks for the development of dysphagia ${ }^{10}$. The insertion of Speech-Language Pathology in Emergency allows for a precise clinical evaluation through the rapid identification of dysphagic patients and an immediate rehabilitation plan for swallowing ${ }^{7,11}$.

The use of alternative feeding routes by patients undergoing hospital care has been reported in several studies, in which the swallowing disorder as an indication factor for these alternative routes was related to diseases such as traumatic brain injury (TBI), decreased level of consciousness, dementia, cognitive deficit, Encephalic Vascular Accident (EVA), severe general condition, and use of mechanical ventilation $^{12,13}$

If nutrient intake by $O R$ is not adequate to meet nutritional needs and/or there is risk of bronchoaspiration, ENT becomes necessary ${ }^{14}$.

ENT by NEP is indicated in neurological/psychiatric cases of EVA, neoplasms, trauma, inflammation, demyelinating diseases, severe depression, anorexia nervosa, oropharyngeal/ esophageal palsy. In cases of gastrointestinal disorders, they are indicated for pancreatitis, inflammatory bowel diseases, short bowel syndrome, chemotherapy, radiotherapy, burns, neonatal inflammatory diseases, and digestive fistulas ${ }^{1,15}$.

It is fundamental for ENT that the time planned for therapy is taken into account ${ }^{4}$, since there is a relationship between dysphagia and the use of alternative feeding routes ${ }^{4,12,16}$, especially when dysphagia is persistent. This aspect is relevant because the use of NEP for periods beyond the period described in the literature is associated to infectious complications of the digestive air tract, pulmonary aspiration of the diet, migration of the probe to the esophagus, lesion of the mucosa of the gastrointestinal tract by the tip of the probe, esophageal stricture, and vocal fold paralysis ${ }^{1,15}$. Studies have already related the use of the NEP to laryngeal traumas such as laryngeal paresis or paralysis, ulcerations and posterior cricoarytenoid muscle infections $s^{4,12}$. As previously described, another complication that might occur is that the use of feeding tubes can cause intense swallowing pain, as well as worsening of symptoms and signs of dysphagia, altered oropharyngeal sensitivity, stasis penetrations/laryngeal aspirations, despite total elimination or minimization of these symptoms after removal $^{17,18}$. It should be emphasized that gastrostomy should be the route of choice when the period of stay for enteral nutrition is longer than six weeks ${ }^{19}$. The decision to use NGT or NET is based, among other aspects, in the presence of GERD and in the risk of aspiration, and both are indicated in cases of short-term use ${ }^{20}$.

Considering the clinical context related to the patient using NEP in the Emergency Department, where there are patients who started using it as a feeding route for the first time, the present study aimed to characterize the population in use of NEP in the emergency department in a public hospital and to identify the main criteria for indications of NEP.

\section{METHODS}

The present study is a cross-sectional retrospective study. The project was evaluated by the Research Ethics Committee of Hospital de Clínicas de Porto Alegre (HCPA) and approved under n. 17-0025.

Since only descriptive analysis were conducted, it was not necessary to calculate the sample size. We analyzed medical records of all patients using NEP in the period between April 1 and September 30, 2016, hospitalized in the Service of Adult Emergency (EMA).

For the identification of patients using NEP, the routine worksheet of the Speech-Language Pathology Service was used, in which the list of all patients with prescription of NEP was recorded. The worksheet is updated daily based on the printing of the "Patient Emergency Nutrition Screening Report" generated by the hospital's AGHUse system, which lists all patients using alternative feeding routes.

Therefore, the study included all patients admitted to the EMA, of both sexes, from 18 years old, using an alternative feeding route, regardless of the underlying disease. Patients with a dietary prescription via jejunostomy or gastrostomy were excluded.

The EMA has registered beds for care by the Brazilian Unified Health System (SUS) in the following 
specialties: Clinical, Gynecology and Surgery. It is a reference in the care of EVA and acute myocardial infection (AMI), with intensive care beds for critical patient care. The site is divided into sectors, where patients are allocated according to their clinical characteristics: Green observation Unit: patients with low clinical risk; Orange Observation Unit: intermediate risk patients; Intermediate Unit: patients who await bed in the wards; and Vascular Unit: severe/instable patients.

Data collection included information regarding age, sex, underlying disease, justification for the use of NEP (oropharyngeal or nutritional), description of nutritional and respiratory status, request for speech therapy assessment, and use of NEP previous to hospitalization. The information were collected according to the adapted form ${ }^{12}$.

We complied with all the Research Guidelines and Regulations involving Human Subjects (Resolution 466/12 of the Brazilian National Health Council), the Internal Regulations of the Research Ethics Committee of the Hospital de Clínicas de Porto Alegre, and filled the forms of Standards for the Use of Hospital Records.

The collected data were stored in a spreadsheet and analyzed in a descriptive and analytical way using the statistical program Statistical Package for Social Sciences (SPSS) 20.0. The chi-square test was used to analyze the relationships, and significance was established at $5 \%(p \leq 0.05)$.

\section{RESULTS}

Data were collected from the medical records of 322 patients, of whom 167 were women (51.9\%). The mean age was $61.61 \pm 22.68$ ranging from a minimum age of 19 years and maximum of 100 .

The underlying diseases presented by the subjects, described in Table 1, were grouped into eight groups. The most prevalent type of disease was neurological and, in relation to comorbidities, $186(57.8 \%)$ patients presented more than one diagnosed disease. Clinical changes such as malnutrition, bronchopneumonia (BCP) and dysphagia were found in $76(23.6 \%)$,
$87(27 \%)$ and $131(40.7 \%)$ cases, respectively. Regarding the request for speech therapist assessment, this request was made for $28(8.7 \%)$ patients, and $260(80.7 \%)$ patients of the sample did not use NEP prior to emergency hospitalization.

When considering the indications for the use of NEP due to the underlying disease (Table 2), low food intake was the most common symptom, followed by dysphagia, and there was a statistically significant

Table 1: Description of the sample regarding clinical aspects.

\begin{tabular}{lcr}
\multicolumn{1}{c}{ Clinical Aspects } & N & $\%$ \\
\hline Underlying Diseases & 168 & 52.2 \\
Neurologic & 95 & 29.5 \\
Cardiologic & 31 & 9.6 \\
Gastrointestinal & 64 & 19.9 \\
Respiratory & 22 & 6.2 \\
Infectious & 67 & 20.8 \\
Metabolic & 36 & 11.2 \\
Head and neck cancer & 116 & 36 \\
Other & & \\
Number of underlying diseases by & & \\
patient & 4 & 1.2 \\
None & 132 & 41 \\
One & 186 & 57.8 \\
More than one & & \\
Bronchopneumonia & 87 & 27 \\
Yes & 235 & 73 \\
No & & \\
Malnutrition & 76 & 23.6 \\
Yes & 273 & 76.4 \\
No & & \\
Dysphagia & 131 & 40.7 \\
Yes & 191 & 59.3 \\
No & & \\
Request of Phonoaudiological & & \\
Assessment & 282 & 19.3 \\
Yes & 260 & 80.7 \\
No & & \\
Previous Nasoenteric Probe & & \\
Yes & & \\
No & & \\
\hline & & \\
\hline
\end{tabular}

Table 2: Distribution of the justifications for the use of Nasoenteric Probe according to underlying disease.

\begin{tabular}{|c|c|c|c|c|c|c|}
\hline \multirow{2}{*}{ Underlying Disease } & RLC & SGC & Dysphagia & OTI & Low food intake & No justification \\
\hline & $\mathbf{N}(\%)$ & $N(\%)$ & $\mathbf{N}(\%)$ & $\mathbf{N}(\%)$ & $N(\%)$ & $N(\%)$ \\
\hline Neurological & $39(12.1 \%)$ & $14(4.3 \%)$ & $61(21.1 \%)$ & $14(4.3 \%)$ & $38(11.8 \%)$ & $35(10.9 \%)$ \\
\hline Cardiac & $31(9.6 \%)^{*}$ & $7(2.2 \%)$ & $30(9.3 \%)$ & $8(2.5 \%)$ & $40(12.5 \%)$ & $15(4.7 \%)$ \\
\hline Gastrointestinal & $6(7.2 \%)$ & $1(3 \%)$ & $6(1.9 \%)$ & $3(0.9 \%)$ & $15(4.7 \%)$ & $8(2.5 \%)$ \\
\hline Pulmonary & $17(5.3 \%)$ & $5(1.6 \%)$ & $23(3.1 \%)$ & $11(3.4 \%)^{*}$ & $22(6.8 \%)$ & $8(2.5 \%)$ \\
\hline Infectious & $3(9 \%)$ & $1(3 \%)$ & $9(2.8 \%)$ & $5(1.6 \%)$ & $11(3.5 \%)$ & $1(0.3 \%)$ \\
\hline Metabolic & $22(6.8)^{*}$ & $8(2.5 \%)$ & $22(6.8 \%)$ & $6(1.9 \%)$ & $23(7.1 \%)$ & $10(3.1 \%)$ \\
\hline Head and neck cancer & $3(9 \%)$ & $3(9 \%)$ & $25(7,8 \%)^{*}$ & $1(0.3 \%)$ & $10(11.2 \%)$ & $4(1.2 \%)$ \\
\hline Other & $31(9.6 \%)$ & $12(3.7 \%)$ & $37(11.5 \%)$ & $10(3.1 \%)$ & $59(18.3 \%)$ & $13(4 \%)$ \\
\hline
\end{tabular}

*Statistically significant values $(\mathrm{p} \leq 0.05)$. RLC = Reduced level of consciousness, SGC = Severe general condition, OTI = orotracheal intubation. 
Table 3: Description of the sample regarding justification for the NEP.

\begin{tabular}{lc}
\hline \multicolumn{1}{c}{ Justifications } & N (\%) \\
\hline No justification & $49(15.2 \%)$ \\
Oropharyngeal cause only & $87(27 \%)$ \\
Nutritional cause only & $142(44 \%)$ \\
Oropharyngeal and nutritional causes & $44(13.6 \%)$ \\
Total & $322(100 \%)$ \\
\hline
\end{tabular}

Data expressed in absolute value.

Table 4: Association between dysphagia and diagnosis of bronchopneumonia and malnutrition.

\begin{tabular}{|c|c|c|c|}
\hline \multirow{2}{*}{ Clinical Findings } & Yes & No & \multirow{2}{*}{$\begin{array}{c}P \\
\text { value }\end{array}$} \\
\hline & $\mathbf{N}(\%)$ & $N(\%)$ & \\
\hline \multicolumn{4}{|l|}{ Bronchopneumonia } \\
\hline Yes & $46(14.3 \%)$ & $41(12.7 \%)$ & $0.01^{*}$ \\
\hline No & $85(26.4 \%)$ & $150(46.6)$ & \\
\hline \multicolumn{4}{|l|}{ Malnutrition } \\
\hline Yes & $36(11.2 \%)$ & $40(12.4 \%)$ & 0.221 \\
\hline No & $95(29.5 \%)$ & $151(46.9 \%)$ & \\
\hline
\end{tabular}

Data expressed in absolute value. *statistically significant $(p \leq 0.05)$. Chi-Square Test Conducted.

difference when considering the distribution of the indications by underlying disease group $(p<0.05)$.

The nutritional causes were the most prevalent reasons for the indication of NEP, i.e., $142(44 \%)$ patients, whereas in $49(15.2 \%)$ medical records there was no description of the indication (Table 3). As oropharyngeal causes, NEP indications were considered for patients with difficulty in swallowing, and the indication for non-oropharyngeal impairment was indicated when the patient presented decreased consciousness level, severe general condition, somnolence, orotracheal intubation, refusal to eat, low oral ingestion and/or inappetence. The cases in which the reason for the SNE indication was not identified were marked as "without justification".

According to the results exposed in Table 4, there was an association between dysphagia and BCP $(p=0.01)$, which did not occur with dysphagia and malnutrition $(p=0.221)$.

\section{DISCUSSION}

The association between the use of alternative feeding measures and an increased risk of developing aspiration pneumonia has been previously described ${ }^{4,15}$, emphasizing that patients who present with dysphagia and use of NEP present accumulation of secretions in the pharynx. Also, the NEP becomes a mechanical impediment to airflow, causing oral breathing in several patients. In addition, the frequent increase in intragastric hydrogenation potential, due to the use of antacid medications, increases the risk of bacterial colonization. As the patient's bed often has a low headboard, reflux of contaminated contents from the esophagus to the pharynx may occur. This situation increases the risk of aspiration and pneumonia, which justifies that the indication be restricted and careful ${ }^{4,21}$.

The results verified in the present study showed that the majority of patients in the sample were elderly $(75.46 \%)$. Thus, it is important to emphasize that aging leads to modifications in the anatomy and physiology of the individual, which, in themselves, already affect the changes in the functionality of the stomatognathic system, and may imply sensory-motor and functional impairments of these structures ${ }^{19,22}$.

In this study, patients with neurological diseases were collected in a single group for statistical analysis, therefore no association between dysphagia and neurological diseases were found, which were described in previous studies. However, in a study that aimed to determine the incidence of dysphagia associated with pulmonary involvement in patients with stroke, it was concluded that the high incidence of dysphagia and pneumonia was consistent in patients with EVA, and the risk of pneumonia was greater in patients with EVA with aspiration ${ }^{23}$. A study conducted in a Brazilian public hospital revealed an incidence of $76.5 \%$ of dysphagia after clinically evaluated EVA, rising to $91 \%$ after videofluoroscopy evaluation ${ }^{24}$, and it was found in another study the significant association between the presence of dysphagia in neurological underlying diseases ${ }^{25}$.

Among the nutritional justifications for the use of NEP, we found the association between reduced level of consciousness/drowsiness both with cardiac diseases and with metabolic diseases. The relation with Diabetes Mellitus (DM) was described as a risk for self-care and increased risk for hypoglycemia. However, the reduced level of consciousness/drowsiness may have different causes, and one of them might be hypoglycemia itself. Sleep disorders are referred to as results of the deleterious effect of DM on the central respiratory control mechanism; therefore, it might be a cause or effect of sleep disorders ${ }^{25-27}$. The associations of excessive daytime somnolence with cardiovascular events have also been described in studies ${ }^{28}$ of the diagnosis of the Obstructive Sleep Apnea Syndrome (OSAS). The association with the SAOS was clearly demonstrated; however, in patients with cardiovascular disorders this association proved to be limited. Furthermore, myocardial ischemia or heart failure alone can lead to fatigue and excessive daytime sleepiness, even in the absence of SAOS, and medications for cardiac problems, such as $\beta$-blockers, can also lead to excessive daytime sleepiness ${ }^{29-31}$. 
There was a statistically significant association between pulmonary diseases and orotracheal intubation (OTI). OTI and invasive mechanical ventilation (IMV) are used to stabilize, protect or maintain compromised or potentially compromised airways. It is one of the most common procedures in the emergency services, being part of the daily practices of the emergency care practitioner, where the arrival of patients in acute respiratory failure or with important lowering of the level of conscience is frequent. Mechanical ventilation (MV) leads to improved gas exchange and decreased respiratory work, being recommended indications for MV, cardiac arrest, respiratory arrest, reduced consciousness, and acute respiratory insufficiency ${ }^{32-35}$. In the present study, $69(21.4 \%)$ patients required NEP due to IOT, as OR feeding was impossible.

Dysphagia is recognized as one of the main risk factors for aspiration pneumonia ${ }^{36,37}$ and oropharyngeal aspiration is an important etiologic factor that can lead to pneumonia in the elderly ${ }^{38}$. Pneumonia by aspiration is difficult to distinguish from other pneumonia syndromes, besides, pneumonia microbiology after macroaspiration has changed in the last 60 years, from an anaerobic infection to aerobic and nosocomial bacnteria ${ }^{39}$. The diagnosis of BCP was present in $27 \%$ of studied cases, and there was an association between this finding and dysphagia. The association between dysphagia and BCP was already reported; however, the literature presents controversial data regarding the relation between tracheal aspiration and altered pulmonary health ${ }^{40-43}$. In 2016, it was identified that most cases of pneumonia among the elderly were by aspiration. With aging, the proportion of pneumonia by aspiration among the cases of hospital pneumonia is increasing dramatically; therefore, in the treatment of pneumonia in the elderly, it should be considered aspiration etiology ${ }^{44}$.

In the present study, no association between dysphagia and malnutrition was identified, although, dysphagia has been described in the literature as a risk factor for malnutrition, which would further reduce functional capacity ${ }^{45}$. The malnutrition process may occur more slowly than dysphagia, and it would not necessarily be related to the development of dysphagia. Another factor to be considered is that the elderly often choose foods that are high in calories but have little nutritional value, as they are easier to chew and swallow ${ }^{46,47}$. It has also been described that there would be no association between nutritional status and risk of dysphagia, but rather an association between dysphagia and the development of Alzheimer's disease ${ }^{48}$, according to another previous study ${ }^{12}$.

Dysphagia is also a symptom associated with head and neck cancer, besides representing a significant complication of the oncologic treatment. Considering the oncological therapy of these types of cancer, it is known that it can result in neuromuscular and sensorial damages that would affect any stage of swallowing, besides influencing the psychological aspects and the quality of life ${ }^{49,50}$. Among other aspects, the mechanisms of protection during swallowing, provided by the structures in the pharynx, are also affected ${ }^{49-51}$, since dysphagia is related to factors such as direct tumor impact, resection type, chemotherapy and radiotherapy. In addition, there are concomitant oral complications, such as xerostomy, which may exacerbate dysphagia and odynophagia ${ }^{52,53}$. It is noteworthy that malnutrition occurs in $30 \%$ to $50 \%$ of cases of head and neck neoplasia, and it is estimated that $57 \%$ of these individuals present significant weight loss before the onset of treatment ${ }^{54}$. Some patients are partially or totally deprived of feeding by OR, which may make it impossible to take adequate ingestion by this route. Thus, ENP or other alternative feeding routes sometimes become a nutritional intervention necessary to prevent weight loss, and, especially, malnutrition ${ }^{54-56}$.

In the present study, 49 (15.2\%) patients did not present a medical record of the reason for prescribing NEP. It should be emphasized that completing the medical record enables communication among members of the multiprofessional team, identification and resolution of the possible issues, continuity of care provided to the individual, and continuous review of work processes ${ }^{57,58}$. Considering this aspect, dysphagia may have been underdiagnosed, although it is one of the main justifications for the indication of an alternative feeding route. In addition, there is a high prevalence of neurological underlying diseases, which often occur with dysphagic conditions ${ }^{23-25}$.

In the present study $131(40.7 \%)$ dysphagic patients were identified, and only $28(8.7 \%)$ requests for phonoaudiological assessment. Therefore, it should be highlighted that, as units of emergency are the areas that provide the first patient care in the case of a severe situation, the action of the phonoaudiologist my be considered fundamental within the multidisciplinary intervention, once there is great demand of potentially dysphagic patients. Considering also the high cost of enteral diets ${ }^{59}$, the assessment and monitoring of dysphagia by a phonoaudiologist may reduce hospital costs, broaden the prospects for prognosis and favor the reduction of hospital stay ${ }^{60,61}$. We add that, as a result of the participation of the phonoaudiologist in the multidisciplinary team, there was a decrease in readmission rates, as well as contribution to the transition to total OR without the need for a complementary nutritional route ${ }^{60,62,63}$. 
The present study did not contemplate the analysis of the time of use of the NEP, and only the first hospitalization was investigated in the period, so it is not possible to identify if there was a request and/or phonoaudiological treatment in cases of transference of patients to other units.

\section{CONCLUSION}

Considering the findings of the present study, when taking into account the whole process of insertion of NEP (from prescription of the probe by the doctor to actual use), and costs for the health system, we highlight that it is fundamental to know the profile and the need of the population treated. The goal is to reduce unnecessary costs to the SUS and to promote patient safety by evaluating what is needed to provide better care.

The role of the phonoaudiologist together with the multi and interdisciplinary team becomes important, since there is a great demand for potentially dysphagic patients who did not use the probe previously as an alternative feeding route. The presence of the speech pathologist would contribute in the decision to prescribe the insertion of a NEP, and it could prevent the deprivation of $O R$ in patients who present safe and effective feeding conditions. Weaning from the NEP avoids the deleterious effects that it can cause.

\section{Conflicts of Interest}

The authors declare no conflicts of interest.

\section{REFERENCES}

1. Waitzberg DL. Nutrição oral, enteral e parenteral na prática clínica. São Paulo: Atheneu; 2009

2. Enrione EB, Gelfand MJ, Morgan D, Sperling M, Wagner SC, Popp $M B$. The effects of rate and route of nutrient intake on protein metabolism. J Surg Res. 1986;40(4):320-5. http://dx.doi.org/10.1016/00224804(86)90194-0. PMid:3084871.

3. Julio R, Mac-Kay APG. Interface entre fonoaudiologia e nutrição: aspectos da alimentação em pacientes idosos hospitalizados. Arq Med Hosp Fac Cienc Med Santa Casa São Paulo São Paulo. 2005;50(3):110-6.

4. Oliveira BSD, Delgado SE, Brescovici SM. Alterações das funções de mastigação e deglutição no processo de alimentação de idosos institucionalizados. Rev Bras Geriatr Gerontol. 2014;17(3):57587. http://dx.doi.org/10.1590/18099823.2014.13065.

5. Groher ME, Bukatman R. The prevalence of swallowing disorders in two teaching hospitals. Dysphagia. 1986;1(1):3-6. http://dx.doi. org/10.1007/BF02408233.

6. Schindler A, Vincon E, Grosso E, Miletto AM, Di Rosa R, Schindler $O$. Rehabilitative management of oropharyngeal dysphagia in acute care settings: data from a large Italian teaching hospital. Dysphagia. 2008;23(3):230-6. http://dx.doi. org/10.1007/s00455-007-9121-4. PMid:17965914.
7. Marques $\mathrm{CHD}$, André $\mathrm{C}$, Rosso ALZ. Disfagia no AVE agudo: revisão sistemática sobre métodos de avaliação. Acta Fisiátrica. 2016;15(2):106-10.

8. Rosenvinge SK, Starke ID. Improving care for patients with dysphagia. Age Ageing. 2005;34(6):587-93. http:// dx.doi.org/10.1093/ageing/afi187. PMid:16267184.

9. Conselho Federal de Fonoaudiologia. Resolução CFFa n 383, de 20 de março de 2010. Dispõe sobre as atribuições e competências relativas à especialidade em Disfagia pelo Conselho Federal de Fonoaudiologia, e dá outras providências. Diário Oficial da União. 2010 Mar 20; 383.

10. Faria KCF, Pessoa ACN, Araújo LI, Paiva MLF. Perfil do paciente atendido pela fonoaudiologia na unidade de urgência e emergência de um hospital universitário. Audiol Commun Res. 2013;18(4):308-13. http://dx.doi.org/10.1590/S231764312013000400012.

11. Itaquy RB, Favero SR, Ribeiro MC, Barea LM, Almeida ST, Mancopes R. Dysphagia and cerebrovascular accident: relationship between severity degree and level of neurological impairment. $J$ Soc Bras Fonoaudiol. 2011;23(4):3859. http://dx.doi.org/10.1590/ S2179-64912011000400016. PMid:22231062.

12. Nogueira SCJ, Carvalho APC, Melo CB, Morais EPG, Chiari BM, Gonçalves MIR. Perfil de pacientes em uso de via alternativa de alimentação internados em um hospital geral. Rev CEFAC. 2013;15(1):94-104. http://dx.doi.org/10.1590/S151618462012005000079.

13. Padovani AR, Andrade CRF. Perfil funcional da deglutição em unidade de terapia intensiva clínica. Einstein (Sao Paulo). 2007;5(4):358-62.

14. Brody R. Nutrition issues in dysphagia: identification, management, and the role of the dietitian. Nutrition in Clinical Practice. 1999;14(5 Suppl):S47-S51.

15. Rosário DM, Marchini JS. Sonda nasogástrica/nasoentérica: cuidados na instalação, na administração da dieta e prevenção de complicações. Medicina (Ribeirão Preto Online). 2002;35(1):95-101.

16. Fujino V, Labns N. Terapia nutricional enteral em pacientes graves: revisão de literatura. Arq Ciênc Saúde. 2007;14(4):220-6.

17. Vale-Prodomo LP, Carrara-De-Angelis E, Barros APB. Avaliação clínica fonoaudiológica das disfagias. In: Jotz GP, Carrara-de-Angelis E, Barros APB. Tratado da deglutição e disfagia: no adulto e na criança. Rio de Janeiro: Revinter; 2009. p. 61-7.

18. Manrique D, Caixêta JAS. Realização de videonasoendoscopia da deglutição na unidade de terapia Intensiva. In: Furkim AM, Rodrigues KA. Disfagias nas unidades de terapia intensiva. São Paulo: Roca; 2015. p. 218-25. 
19. Almeida ST, Gentil BC, Nunes EL. Alterações miofuncionais orofaciais associadas ao processo de envelhecimento em um grupo de idosos institucionalizados. Revista Brasileira de Ciências do Envelhecimento Humano. 2013;9(2):282-92.

20. Philippsen EB. Uso de terapia nutricional enteral via sonda em pacientes hospitalizados. Especialize Rev On-line IPOG. 2015;1(10):1-16.

21. Dziewas R, Warnecke T, Hamacher C, Oelenberg S, Teismann I, Kraemer $\mathrm{C}$, et al. Do nasogastric tubes worsen dysphagia in patients with acute stroke? BMC Neurol. 2008;8:28. http:// dx.doi.org/10.1186/1471-2377-8-28. PMid:18651972.

22. Oliveira BSD, Delgado SE, Brescovici SM. Alterações das funções de mastigação e deglutição no processo de alimentação de idosos institucionalizados. Rev Bras Geriatr Gerontol. 2014;17(3):57587. http://dx.doi.org/10.1590/18099823.2014.13065

23. Martino R, Foley N, Bhogal S, Diamant N, Speechley M, Teasell R. Dysphagia after stroke: incidence, diagnosis, and pulmonary complications. Stroke. 2005;36(12):2756-63. http://dx.doi.org/10.1161/01. STR.0000190056.76543.eb. PMid:16269630.

24. Schelp AO, Cola PC, Gatto AR, Silva RG, Carvalho LR. Incidência de disfagia orofaríngea após acidente vascular encefálico em hospital público de referência. Arq Neuropsiquiatr. 2004;62(2B):5036. http://dx.doi.org/10.1590/ S0004-282X2004000300023. PMid:15273852.

25. Moraes AMS, Coelho WJP, Castro G, Nemr K. Incidência de disfagia em unidade de terapia intensiva de adultos. Rev CEFAC. 2006;8(2):171-7.

26. Cunha MC, Zanetti ML, Hass VJ. Sleep quality in type 2 diabetics. Rev Lat Am Enfermagem. 2008;16(5):8505. http://dx.doi.org/10.1590/ S0104-11692008000500009. PMid:19061021.

27. Medeiros $C$, Bruin $V$, Férrer $D$, Paiva T, Montenegro Júnior R, Forti A, et al. Excessive daytime sleepiness in type 2 diabetes. Arq Bras Endocrinol Metabol. 2013;57(6):425-
30. http://dx.doi.org/10.1590/ S0004-27302013000600003. PMid:24030181.

28. Andrechuk CRS, Ceolim MF. Sonolência diurna excessiva nos pacientes com infarto agudo do miocárdio. Acta Paul Enferm. 2015;28(3):230-6. http://dx.doi. org/10.1590/1982-0194201500039.

29. Lee C-H, Ng W-Y, Hau W, Ho H-H, Tai B-C, Chan MY, et al. Excessive daytime sleepiness is associated with longer culprit lesion and adverse outcomes in patients with coronary artery disease. J Clin Sleep Med. 2013;9(12):1267-72. PMid:24340288.

30. Martynowicz H, Skomro R, Gać $P$, Mazur G, Porębska I, Bryłka A, et al. The influence of hypertension on daytime sleepiness in obstructive sleep apnea. J Am Soc Hypertens. 2017;11(5):295-302. http://dx.doi. org/10.1016/j.jash.2017.03.004. PMid:28412276.

31. Jaussent I, Empana JP, Ancelin ML, Besset A, Helmer C, Tzourio C, et al. Insomnia, daytime sleepiness and cardio-cerebrovascular diseases in the elderly: a 6 -year prospective study. PLoS One. 2013;8(2):e56048. http://dx.doi.org/10.1371/journal. pone.0056048. PMid:23457496.

32. Jezler S, Holanda MA, José A, Franca S. Ventilação mecânica na doença pulmonar obstrutiva crônica (DPOC) descompensada. J Bras Pneumol. 2007;33(Suppl 2):111-8. http://dx.doi.org/10.1590/S180637132007000800006 .

33. Barbas CSV, Ísola AM, Farias AMC, Cavalcanti AB, Gama AMC, Duarte ACM, et al. Recomendações brasileiras de ventilação mecânica 2013. Parte I. Rev Bras Ter Intensiva. 2014;26(2):89-121. http://dx.doi. org/10.5935/0103-507X.20140017. PMid:25028944.

34. Damasceno MPCD, David CMN, Souza PCSP, Chiavone PA, Cardoso LTQ, Amaral JLG, et al. Ventilação mecânica no Brasil: aspectos epidemiológicos. Rev Bras Ter Intensiva. 2006;18(3):21928. http://dx.doi.org/10.1590/ S0103-507X2006000300002. PMid:25310434.

35. Tallo FS, Vendrame LS, Lopes RD, Lopes AC. Ventilação mecânica invasiva na sala de emergência: uma revisão para o clínico. Rev Bras Clin Med. 2013;11(1):48-54.
36. Mann G, Hankey GJ. Initial clinical and demographic predictors of swallowing impairment following acute stroke. Dysphagia. 2001;16(3):208-15. http://dx.doi.org/10.1007/s00455-0010069-5. PMid:11453569.

37. Smithard DG, O'Neill PA, Park C, Morris J, Wyatt R, England R, et al. Complications and outcome after acute stroke. Does dysphagia matter? Stroke. 1996;27(7):1200-4. http:// dx.doi.org/10.1161/01.STR.27.7.1200. PMid:8685928.

38. Marik PE, Kaplan D. Aspiration pneumonia and dysphagia in the elderly. Chest. 2003;124(1):32836. http://dx.doi.org/10.1378/ chest.124.1.328. PMid:12853541.

39. DiBardino DM, Wunderink RG. Aspiration pneumonia: a review of modern trends. J Crit Care. 2015;30(1):40-8. http://dx.doi. org/10.1016/j.jcrc.2014.07.011. PMid:25129577.

40. Toufen C JR, Camargo FP, Carvalho CRR. Pneumonia aspirativa associada a alterações da deglutição: relato de caso. Rev Bras Ter Intensiva. 2007;19(1):11822. http://dx.doi.org/10.1590/ S0103-507X2007000100016. PMid:25310669.

41. Chojin $\mathrm{Y}$, Kato T, Rikihisa M, Omori $\mathrm{M}$, Noguchi S, Akata K, et al. Evaluation of the mann assessment of swallowing ability in elderly patients with pneumonia. Aging Dis. 2017;8(4):42033. PMid:28840057.

42. Nakamori M, Hosomi N, Ishikawa K, Imamura E, Shishido T, Ohshita $\mathrm{T}$, et al. Prediction of pneumonia in acute stroke patients using tongue pressure measurements. PLoS One. 2016;11(11):e0165837. http://dx.doi. org/10.1371/journal.pone.0165837. PMid:27802333.

43. Marik PE. Aspiration Pneumonitis and Aspiration Pneumonia. N Engl J Med. 2001;344(9):665-71. http://dx.doi. org/10.1056/NEJM200103013440908. PMid:11228282.

44. Ebihara S, Sekiya H, Miyagi M, Ebihara T, Okazaki T. Dysphagia, dystussia, and aspiration pneumonia in elderly people. J Thorac Dis. 2016;8(3):632-9. http://dx.doi. org/10.21037/jtd.2016.02.60. PMid:27076964. 
45. Serra-Prat M, Palomera M, Gomez C, Sar-Shalom D, Saiz A, Montoya JG, et al. Oropharyngeal dysphagia as a risk factor for malnutrition and lower respiratory tract infection in independently living older persons: a population-based prospective study. Age Ageing. 2012;41(3):376-81. http:// dx.doi.org/10.1093/ageing/afs006. PMid:22311895.

46. Freitas AMP, Philippi ST, Ribeiro SML. Listas de alimentos relacionadas ao consumo alimentar de um grupo de idosos: análises e perspectivas. Rev Bras Epidemiol. 2011;14:161-77.

47. Sura L, Madhavan A, Carnaby G, Crary MA. Dysphagia in the elderly: management and nutritional considerations. Clin Interv Aging. 2012;7:287-98. PMid:22956864.

48. Goes VF, Mello-Carpes PB, Oliveira LO, Hack J, Magro M, Bonini JS. Evaluation of dysphagia risk, nutritional status and caloric intake in elderly patients with Alzheimer's. Rev Lat Am Enfermagem. 2014;22(2):31724. http://dx.doi.org/10.1590/0104 1169.3252.2418. PMid:26107841.

49. Patterson JM, McColl E, Wilson J, Carding P, Rapley T. Head and neck cancer patients' perceptions of swallowing following chemoradiotherapy. Support Care Cancer. 2015;23(12):3531-8. http:// dx.doi.org/10.1007/s00520-015-27158. PMid:25851803.

50. Carrera M, Medrado ARAP, Martins GB, Lima HR, Marques RSO, Costa AS. Qualidade de vida em deglutição e câncer de cabeça e pescoço: revisão de literatura. Revista Bahiana de Odontologia. 2017;8(1):26-32.

51. Manikantan K, Khode S, Sayed SI, Roe J, Nutting CM, Rhys-Evans $P$, et al. Dysphagia in head and neck cancer. Cancer Treat Rev. 2009;35(8):724-32. http://dx.doi. org/10.1016/j.ctrv.2009.08.008. PMid:19751966.

52. Raber-Durlacher JE, Brennan MT, Leeuw IMV, Gibson RJ, Eilers JG, Waltimo T. Swallowing dysfunction in cancer patients. Support Care Cancer. 2012;20(3):433-43. http://dx.doi. org/10.1007/s00520-011-1342-2. PMid:22205548.

53. Nguyen NP, Frank C, Moltz CC, Vos P, Smith HJ, Karlsson U, et al. Impact of dysphagia on quality of life after treatment of head-andneck cancer. Int J Radiat Oncol Biol Phys. 2005;61(3):772-8. http://dx.doi. org/10.1016/j.ijrobp.2004.06.017. PMid:15708256.

54. Takara TFM, Wilson Morikawa W, Vivacqua RR, Trevisan C, Ando ET, Carvalho G, et al. Avaliação nutricional em pacientes com câncer de cabeça e pescoço. Rev Bras Cir Cabeça Pescoço. 2012;41(2):70-4.

55. Bozzetti F, Arends J, Lundholm K, Micklewright A, Zurcher G, Muscaritoli $M$. ESPEN guidelines on parenteral nutrition: non-surgical oncology. Clin Nutr. 2009;28(4):445-54. http://dx.doi. org/10.1016/j.clnu.2009.04.011. PMid:19477052.

56. Piquet MA, Ozsahin M, Larpin I, Zouhair A, Coti P, Monney M, et al. Early nutritional intervention in oropharyngeal cancer patients undergoing radiotherapy. Support Care Cancer. 2002;10(6):502-4. http:// dx.doi.org/10.1007/s00520-002-03641. PMid:12353130.

57. Conselho Federal de Medicina. Resolução no 1.638/2002. Define prontuário médico e torna obrigatória a criação da Comissão de Revisão de
Prontuários nas instituições de saúde. Diário Oficial da União. 2002 Set 30; 1.638.

58. Pinto VB. Prontuário eletrônico do paciente: documento técnico de informação e comunicação do domínio da saúde. Encontros Bibli. 2006;11(21):34-48.

https://doi.org/10.5007/15182924.2006v11n21p34.

59. Zunta RSB, Castilho V. Faturamento de procedimentos de enfermagem em uma Unidade de Terapia Intensiva. Rev Lat Am Enfermagem. 2011;19(3):1-9.

60. Santos MA. Caracterização de pacientes disfágicos atendidos pelo setor de fonoaudiologia: estágio em um hospital universitário [monografia]. Florianópolis: Universidade Federal de Santa Catarina; 2015.

61. Abdulmassih EMS, Macedo EDM Fo, Santos RS, Jurkiewicz AL. Evolution of patients with oropharyngeal dysphasia in hospital environment. Int Arch Otorhinolaryngol. 2009;13(1):55-62.

62. Furkim AM, Sacco ABF. Eficácia da fonoterapia em disfagia neurogênica usando a escala funcional de ingestão por via oral (FOIS) como marcador. Rev CEFAC. 2008;10(4):503-12. http://dx.doi.org/10.1590/S151618462008000400010.

63. Silva DLR, Lira FOQ, Oliveira JCC, Canuto MSB. Atuação da fonoaudiologia em unidade de terapia intensiva de um hospital de doenças infecciosas de Alagoas. Rev CEFAC. 2016;18(1):174-83. http://dx.doi.org/10.1590/19820216201618112015. 